\title{
Key issues surrounding the management of non- communicable diseases including the management of diabetes post COVID-19 among developing countries with a specific focus on Bangladesh
}

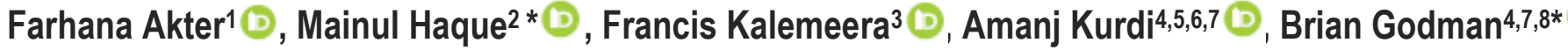

\footnotetext{
${ }^{1}$ Department of Endocrinology, Chittagong Medical College, Bangladesh.

${ }^{2}$ Unit of Pharmacology, Faculty of Medicine and Defence Health, Universiti Pertahanan Nasional Malaysia (National Defence University of Malaysia), Kem Sungai, Besi, 57000 Kuala Lumpur, Malaysia.

Email: runurono@gmail.com.

${ }^{3}$ Department of Pharmacy Practice and Policy, School of Pharmacy, Faculty of Health Sciences, University of Namibia, Namibia.

${ }^{4}$ Strathclyde Institute of Pharmacy and Biomedical Sciences, University of Strathclyde, Glasgow, United Kingdom.

Email: brian.godman@strath.ac.uk.

${ }^{5}$ Department of Pharmacology, College of Pharmacy, Hawler Medical University, Erbil, Iraq.

${ }^{6}$ Center of Research and strategic studies, Lebanese French University, Erbil, Kurdistan Region Government, Iraq

${ }^{7}$ Division of Public Health Pharmacy and Management, School of Pharmacy, Sefako Makgatho Health Sciences University, Pretoria, South Africa. Email: brian.godman@smu.ac.za

${ }^{8}$ Centre of Medical and Bio-allied Health Sciences Research, Ajman University, Ajman, United Arab Emirates
}

*Corerspondence Authors
(Khanam et al., 2019). For instance in Bangladesh, deaths due to NCDs increased from $43.4 \%$ of total deaths in 2000 to $66.9 \%$ in 2015 (Rawal et al., 2019). It has been estimated by 2025 that nearly $30 \%$ of adults globally will have hypertension estimated at 1.5 billion people (Khanam et al., 2019, Legido-Quigley et al., 2019), with these figures likely to be an under-estimate with the recent COVID-19 pandemic and associated lockdown measures (Ahmed et al., 2020, Kluge et al., 2020, Mistry et al., 2021), further increasing morbidity and mortality. There are similar concerns with patients with diabetes mellitus. Globally in 2019, there was an estimated 463 million people worldwide with diabetes mellitus (Chan et al., 2021, Liu et al., 2020), with these rates expected to grow unless addressed (Godman et al., 2021a). However, the International Diabetes Federation (IDF) recorded higher rates globally at 537 million adults aged between 20 and 70 years, i.e., approximately one in ten adults, with this figure expected to rise to 643 million by 2030 unless addressed (IDF, 2021a).

The increase in morbidity and mortality due to NCDs, including diabetes and hypertension, among LMICs, including African and South Asian countries, has been exacerbated by a number of key factors. These include increasing urbanisation, concerns with access to diagnosis and treatment facilities exacerbated by high co-payment levels and resource issues, family history, ageing populations, dietary habits and limited education (Alam Miah and Yousuf, 2018, Bhuyan and Fardus, 2019, Fottrell et al., 2018, Godman et al., 2020, Kibria et al., 2018, Macquart de 
Terline et al., 2019). In addition, continued high tobacco consumption including among African and Asian countries further aggravates the condition (Rafique et al., 2018, Hango et al., 2021). This includes Bangladesh where up to $44.7 \%$ of men smoke (Burki, 2019, Rafique et al., 2018), highest in the slum population of Dhaka City (Khandker et al., 2017). However, this may start to change with new tobacco laws and the introduction of smoke-free places in Bangladesh as well as monitoring of the implementation of the Tobacco Control Act by local regions in Bangladesh (Tobacco Control Laws, 2021). Overall, NCDs including hypertension and diabetes are particularly prevalent in LMICs, which need urgently to be addressed to reduce future morbidity and mortality (Khanam et al., 2019).

Within Bangladesh, Rahman et al. (2018) estimated that $20 \%$ of the adult population have hypertension (Rahman et al., 2018). Fottrell et al. (2018), Khanan et al. (2019) and Chowdhury et al. (2020) in their systematic review and meta-analysis reported similar prevalence rates (Khanam et al., 2019, Chowdhury et al., 2020, Fottrell et al., 2018), with Hassan et al. (2021) recently reporting higher rates of hypertension among urban and rural areas of Dhaka (Hasan et al., 2021). Overall, prevalence rates for hypertension are likely to rise certainly in the short to medium term in Bangladesh unless addressed (Chowdhury et al., 2020). This is without taking into consideration the impact of COVID-19 on the diagnosis and management of hypertension through lockdown and other activities (Kluge et al., 2020).

In their study, Fottrell et al. (2018) also found that the combined prevalence of impaired fasting glucose and glucose intolerance alongside diabetes among the population in Bangladesh was $34.9 \%$ among women and $26.1 \%$ among men, with both increasing with age (Fottrell et al., 2018). Mistry et al. (2021) estimated that nearly $60 \%$ of surveyed elderly in Bangladesh had at least one NCD with one-quarter having multimorbidities (Mistry et al., 2021). Overall, an estimated 8.4 million adults aged between 20 and 79 in Bangladesh have diabetes, with the number of patients with diabetes projected to rise (Afroz et al., 2019a). The International Diabetes Federation in their latest publication suggest this could be as high as 16.8 million adults in 2030 in Bangladesh and 22.3million by 2045 unless addressed, enhanced by an estimated $43.5 \%$ undiagnosed (IDF, 2021b). There are generally appreciable rates of misdiagnosis of diabetes in Southeast Asia, including Bangladesh, due to many people not being included in any coverage programme (Shariful Islam et al., 2017). COVID-19 itself can potentially increase the number of people who develop type 1 diabetes (T1DM) (Steenblock et al., 2021). Alongside this, impairment of islet function should be considered in patients with metabolic disorders following COVID-19 as this virus can increase the potential for these patients to develop T2DM (Maestre-Muñiz et al., 2021, Steenblock et al., 2021, Accili, 2021).

High prevalence rates for NCDs including diabetes and hypertension have appreciable economic consequences. In the case of patients with diabetes, the cost of associated complications has increased the global economic burden from US\$1.3 trillion in 2015 to an estimated US\$2.1 to US\$2.5 trillion by 2030 (Bommer et al., 2018, Mapa-Tassou et al., 2019). This includes both direct and indirect costs, and equates to an average of $2.2 \%$ of Gross Domestic Product (GDP), with most of these costs being indirect costs (Bommer et al., 2018, Mapa-Tassou et al., 2019). The cost of complications is enhanced by their high prevalence rates if inadequate preventative measures (Chan et al., 2021). In their recent study, Afroz et al. (2019a) found that among 1253 patients with type 2 diabetes (T2DM) surveyed in six hospitals in Bangladesh, the prevalence of strokes was $10.1 \%$, coronary artery disease $30.5 \%$, diabetic foot ulcerations $12.0 \%$, nephropathy $34.2 \%$, retinopathy $25.1 \%$ and neuropathy at $5.8 \%$ of patients (Afroz et al., 2019b).

The costs of care are particular concern in countries such as Bangladesh due to high rates of patient co-payments (Rahman et al., 2020, Khan et al., 2017, Haque et al., 2021a). In their study, Shariful Islam et al. (2017) estimated that the total annual per capita expenditure on medical care among patients in Bangladesh was 6.1 times greater for those with diabetes versus those without diabetes (Shariful Islam et al., 2017). Afroz et al. (2019) calculated that the costs of medicines contributed the greatest amount to the overall direct costs of treating patients with diabetes in Bangladesh $(60.7 \%)$ followed by the costs of hospitalisations (27.7\%) (Afroz et al., 2019a). Greater proactivity in managing these patients in Bangladesh will bring considerable improvement in patient outcomes alongside net economic benefits given the current high costs of managing patients with NCDs including those with diabetes and hypertension (Nugent et al., 2017, Afroz et al., 2019a).

We are aware that whilst the Government in Bangladesh has launched many NCD-related programmes and policies in recent years to improve the management of patients with NCDs, including those with diabetes and hypertension (Nugent et al., 2017, Biswas et al., 2017), there are concerns. Concerns include the fact that despite these initiatives there appears a lack of effective planning, implementation and monitoring (Biswas et al., 2017). As a result, the burden of NCDs continues to grow in Bangladesh (Biswas et al., 2017).

Typically in Bangladesh, patients with NCDs in the public sector, including diabetes and hypertension, may visit health complexes before referred to more specialist clinics (Rawal et 
al., 2019). Whilst these services have improved in recent years, there are concerns generally with the lack of specific guidelines, trained personnel, laboratory facilities, and medicines including metformin and insulin for patients with diabetes, as well as typically poor recording of patients' treatments and reporting systems (Rawal et al., 2019). This was emphasised in the study of Biswas et al. (2018) among health facilities throughout Bangladesh providing care for patients with cardiovascular diseases (CVD) and diabetes (Biswas et al., 2018). The authors found a shortage of trained staff and a lack of adequate medicine supplies for patients with CVD (43.9\%) and diabetes (23.5\%). Overall, among the health facilities that offered care for patients with CVD and diabetes, less than $1 \%$ had all four designated service readiness factors including the availability of guidelines, trained staff and equipment as well as appropriate medicine (Biswas et al., 2018). The availability and use of current guidelines is seen as especially important to improve future care (Campbell et al., 2021, Niaz et al., 2019). Similar findings were seen by Legido-Quigley et al. (2019) where patients with hypertension had concerns with accessing health care including medicines (Legido-Quigley et al., 2019).

Encouragingly, we have seen in Bangladesh a growth in the availability of newer long-acting insulin analogues to help address issues of patient convenience and incidences of hypoglycaemia in recent years (Haque et al., 2021a). This has been helped by the increasing availability of low cost longacting insulin analogue biosimilars, different to the situation among a number of African countries including those with universal healthcare (Haque et al., 2021a, Haque et al., 2021b, Godman et al., 2021a, Godman et al., 2021b, Godman et al., 2021c). However, as mentioned, there are concerns with diagnosis and monitoring of patients with diabetes including adherence to prescribed medicines. We have initiated a pilot study to explore this more closely starting with patients with T2DM in out-patient clinics of public hospitals as poor record keeping and monitoring will compromise future care. This builds on studies across Bangladesh and LMICs (Afroz et al., 2019b, Mwita et al., 2020, Mwita et al., 2019, Chetoui et al., 2020, Pinchevsky et al., 2017).

In conclusion, there are considerable concerns with the current management of patients with NCDs across LMICs further aggravated by the recent COVID-19 pandemic. Suggestions for the Government in Bangladesh to improve the future management of patients with NCDs, especially those with diabetes, include prioritizing vulnerable populations through for instance subsidizing high costs of care for patients with NCDs when the need arises (Rahman et al., 2020). In addition, improving diagnosis as well as access and availability to medicines to adequately treat patients with NCDs including those with T2DM (Ozawa et al., 2019, Ewen et al., 2019).
Alongside this, being proactive generally regarding the management of NCDs in line with suggested National programmes, with, as mentioned, such approaches estimated to provide appreciable net economic and healthcare benefits given current costs (Nugent et al., 2017). Improved information technology can also help with data collection and analysis given the predominantly paper based approaches currently within Bangladesh with concerns with the adequate monitoring of patients (Islam, 2016). Furthermore, potentially exploring the utilisation of innovative technologies as well as greater use of telemedicine, including mobile telephones, to change patient behaviour, especially their lifestyles (Tabassum et al., 2018). We will be exploring and monitoring a number of aspects in future studies.

\section{FUNDING}

There was no funding for this editorial.

\section{CONFLICTS OF INTEREST}

The authors declare they have no relevant conflicts of interest.

\section{REFERENCES}

Accili D. Can COVID-19 cause diabetes? Nat Metab. 2021;3(2):123125. https://doi.org/ 10.1038/s42255-020-00339-7

Afroz A, Alam K, Ali L, Karim A, Alramadan MJ, Habib SH, Magliano DJ, Billah B. Type 2 diabetes mellitus in Bangladesh: a prevalence based cost-of-illness study. BMC Health Serv Res. 2019a;19(1):601. https://doi.org/ 10.1186/s12913-019-4440-3

Afroz A, Zhang W, Wei Loh AJ, Jie Lee DX, Billah B. Macro- and micro-vascular complications and their determinants among people with type 2 diabetes in Bangladesh. Diabetes Metab Syndr. 2019b;13(5):2939-2946. https://doi.org/ 10.1016/j.dsx.2019.07.046

Ahmed SAKS, Ajisola M, Azeem K, Bakibinga P, Chen YF, Choudhury NN, Fayehun O, Griffiths F, Harris B, Kibe P, Lilford RJ, Omigbodun A, Rizvi N, Sartori J, Smith S, Watson SI, Wilson R, Yeboah G, Aujla N, Azam SI, Diggle PJ, Gill P, Iqbal R, Kabaria C, Kisia L, Kyobutungi C, Madan JJ, Mberu B, Mohamed SF, Nazish A, Odubanjo O, Osuh ME, Owoaje E, Oyebode O, Porto de Albuquerque J, Rahman O, Tabani K, Taiwo OJ, Tregonning G, Uthman OA, Yusuf R; Improving Health in Slums Collaborative. Impact of the societal response to COVID-19 on access to healthcare for non-COVID-19 health issues in slum communities of Bangladesh, Kenya, Nigeria and Pakistan: results of pre-COVID and COVID19 lockdown stakeholder engagements. BMJ Glob Health. 2020;5(8):e003042. https://doi.org/ 10.1136/bmjgh-2020-003042.

Alam Miah MB, Yousuf MA. Analysis the significant risk factors on type 2 diabetes perspective of Bangladesh. Diabetes Metab Syndr. 2018; 12(6):897-902. https://doi.org/ 10.1016/j.dsx.2018.05. 012.

Bhuyan KC, Fardus J. Factors Responsible for Diabetes Among Adult People of Bangladesh. Am J Biomed Sci \& Res. 2019; 2(4): 137-42. https://doi.org/ 10.34297/AJBSR.2019.02.000593

Biswas T, Pervin S, Tanim MIA, Niessen L, Islam A. Bangladesh policy on prevention and control of non-communicable diseases: a policy analysis. BMC Public Health. 2017;17(1):582. https://doi.org/ 10.1186/s12889017-4494-2.

Biswas T, Haider MM, Das Gupta R, Uddin J. Assessing the readiness of health facilities for diabetes and cardiovascular services in Bangladesh: a 
cross-sectional survey. BMJ Open. 2018;8(10): e022817. https://doi.org/ 10.1136/bmjopen-2018-022817. P

Bommer C, Sagalova V, Heesemann E, Manne-Goehler J, Atun R, Bärnighausen T, Davies J, Vollmer S. Global Economic Burden of Diabetes in Adults: Projections From 2015 to 2030. Diabetes Care. 2018;41(5):963-970. https://doi.org/ 10.2337/dc17-1962.

Burki TK. Tobacco consumption in Bangladesh. Lancet Oncol. 2019;20(4):478. https://doi.org/ 10.1016/S1470-2045(19)30144-5.

Campbell S, Meyer JC, Godman B. Why compliance to national prescribing guidelines is important especially across sub-Saharan Africa and suggestions for the future. J Biomed Pharm Sci. 2021; 4 (6):1-7.

Chan JCN, Lim LL, Wareham NJ, Shaw JE, Orchard TJ, Zhang P, Lau ESH, Eliasson B, Kong APS, Ezzati M, Aguilar-Salinas CA, McGill M, Levitt NS, Ning G, So WY, Adams J, Bracco P, Forouhi NG, Gregory GA, Guo J, Hua X, Klatman EL, Magliano DJ, Ng BP, Ogilvie D, Panter J, Pavkov M, Shao H, Unwin N, White M, Wou C, Ma RCW, Schmidt MI, Ramachandran A, Seino Y, Bennett PH, Oldenburg B, Gagliardino JJ, Luk AOY, Clarke PM, Ogle GD, Davies MJ, Holman RR, Gregg EW. The Lancet Commission on diabetes: using data to transform diabetes care and patient lives. Lancet. 2021; 396(10267): 2019-2082. https://doi.org/10.1016/S0140-6736(20)32374-6.

Chetoui A, Kaoutar K, Elmoussaoui S, Boutahar K, El Kardoudi A, Chigr F, Najimi M. Prevalence and determinants of poor glycaemic control: a cross-sectional study among Moroccan type 2 diabetes patients. Int Health. 2020:ihz107. https://doi.org/ 10.1093/inthealth/ihz107.

Chowdhury MZI, Rahman M, Akter T, Akhter T, Ahmed A, Shovon MA, Farhana Z, Chowdhury N, Turin TC. Hypertension prevalence and its trend in Bangladesh: evidence from a systematic review and meta-analysis. Clin Hypertens. 2020;26:10. https://doi.org/ 10.1186/s40885-020-00143-1.

Ewen M, Joosse HJ, Beran D, Laing R. Insulin prices, availability and affordability in 13 low-income and middle-income countries. BMJ Glob Health. 2019;4(3):e001410. https://doi.org/ 10.1136/bmjgh-2019-001410.

Fottrell E, Ahmed N, Shaha SK, Jennings H, Kuddus A, Morrison J, Akter K, Nahar B, Nahar T, Haghparast-Bidgoli H, Khan AKA, Costello A, Azad K. Distribution of diabetes, hypertension and non-communicable disease risk factors among adults in rural Bangladesh: a cross-sectional survey. BMJ Glob Health. 2018;3(6):e000787. https://doi.org/ 10.1136/bmjgh-2018-000787.

Godman B, Basu D, Pillay Y, Mwita JC, Rwegerera GM, Anand Paramadhas BD, Tiroyakgosi C, Okwen PM, Niba LL, Nonvignon J, Sefah I, Oluka M, Guantai AN, Kibuule D, Kalemeera F, Mubita M, Fadare J, Ogunleye OO, Distiller LA, Rampamba EM, Wing J, Mueller D, Alfadl A, Amu AA, Matsebula Z, Kalungia A, Zaranyika T, Masuka N, Wale J, Hill R, Kurdi A, Timoney A, Campbell S, Meyer JC. Review of Ongoing Activities and Challenges to Improve the Care of Patients With Type 2 Diabetes Across Africa and the Implications for the Future. Front Pharmacol. 2020;11:108. https://doi.org/ 10.3389/fphar.2020.00108.

Godman B, Leong T, Abubakar AR, Kurdi A, Kalemeera F, Rwegerera GM, Patrick O, Niba LL, Ibrahim K, Amu AA, Matowa P, Acolatse J, Incoom R, Sefah IA, Opanga S, Njeri LW, Kimonge D, Oluka M, Chikowe I, Khuluza F, Phiri H, Kibuule D, Hango E, Sani IH, Malande OO, Piloya-Were T, Alutuli L, Kalungia AC, Chaibva BV, Zaranyika T, Haque M, Allocati E, Campbell S, Adwubi ET, Ogunleye OO. Availability and Use of Long-Acting Insulin Analogues Including Their Biosimilars across Africa: Findings and Implications. Intern Med. 2021a; 11:343.

Godman B, Haque M, Kumar S, Islam S, Charan J, Akter F, Kurdi A, Allocati E, Bakar MA, Rahim SA, Sultana N, Deeba F, Halim Khan MA, Alam ABMM, Jahan I, Kamal ZM, Hasin H, Munzur-E-Murshid, Nahar S, Haque M, Dutta S, Abhayanand JP, Kaur RJ, Acharya J, Sugahara T, Kwon HY, Bae S, Khuan KKP, Khan TA, Hussain S, Saleem Z, Pisana A, Wale J, Jakovljevic M. Current utilization patterns for long-acting insulin analogues including biosimilars among selected Asian countries and the implications for the future. Curr Med Res Opin. 2021b;37(9):1529-1545. https://doi.org/10.1080/ 03007995.2021.1946024.

Godman B, Haque M, Leong T, Allocati E, Kumar S, Islam S, Charan J, Akter F, Kurdi A, Vassalo C, Bakar MA, Rahim SA, Sultana N, Deeba F,
Khan MAH, Alam ABMM, Jahan I, Kamal ZM, Hasin H, Munzur-E-Murshid, Nahar S, Haque M, Dutta S, Abhayanand JP, Kaur RJ, Rwegerera GM, do Nascimento RCRM, Dias Godói IP, Irfan M, Amu AA, Matowa P, Acolatse J, Incoom R, Sefah IA, Acharya J, Opanga S, Njeri LW, Kimonge D, Kwon HY, Bae S, Khuan KKP, Abubakar AR, Sani IH, Khan TA, Hussain S, Saleem Z, Malande OO, Piloya-Were T, Gambogi R, Hernandez Ortiz C, Alutuli L, Kalungia AC, Hoxha I, Marković-Peković V, Tubic B, Petrova G, Tachkov K, Laius O, Harsanyi A, Inotai A, Jakupi A, Henkuzens S, Garuoliene K, Gulbinovič J, Wladysiuk M, Rutkowski J, Mardare I, Fürst J, McTaggart S, MacBride-Stewart S, Pontes C, Zara C, Tagoe ET, Banzi R, Wale J, Jakovljevic M. The Current Situation Regarding Long-Acting Insulin Analogues Including Biosimilars Among African, Asian, European, and South American Countries; Findings and Implications for the Future. Front Public Health. 2021c;9:671961. https://doi.org/ 10.3389/fpubh.2021.671961.

Hango E, Amakali K, Shilunga A, Kibuule D, Godman B, Kalemeera F. Assessing smoking cessation services and pharmacotherapy in Namibia; findings and implications for future policy initiatives. Expert Rev Pharmacoecon Outcomes Res. 2021. https://doi.org/10.1080/14737167.2022. 2000863

Haque M, Islam S, Kamal ZM, Akter F, Jahan I, Rahim MSA, Sultana N, Alam AM, Munzur-E-Murshid, Halim-Khan MA, Deeba F, Bakar MA, Nahar S, Mozaffor M, Urmi UL, Saikat TR, Islam MZ, Haque M, Iqbal S, Hossain MM, Naher N, Allocati E, Godman B. Ongoing efforts to improve the management of patients with diabetes in Bangladesh and the implications. Hosp Pract. 2021a;49(4):266-272. https://doi.org/ 10.1080/21548331.2021.1906083.

Haque M, Islam S, Abubakar AR, Sani IH, Opanga S, Kamal ZM, Akter F, Godman B. Utilization and expenditure on long-acting insulin analogs among selected middle-income countries with high patient co-payment levels: findings and implications for the future. J Appl Pharm Sci. 2021b; 11(07): 172182. https://doi.org/10.7324/ JAPS.2021.110720

Hasan M, Khan MSA, Sutradhar I, Hossain MM, Hossaine M, Yoshimura Y, Choudhury SR, Sarker M, Mridha MK. Prevalence and associated factors of hypertension in selected urban and rural areas of Dhaka, Bangladesh: findings from SHASTO baseline survey. BMJ Open. 2021;11(1):e038975. https://doi.org/ 10.1136/bmjopen-2020-038975.

IDF. International Diabetes Federation (IDF) Diabetes Atlas. Diabetes around the world in 2021a. Available at URL: https://diabetesatlas.org/ [Accesed November 26, 2021]

IDF. International Diabetes Federation Diabetes Atlas. Diabetes around the world in 2021b. Bangladesh. Available at URL: https://diabetesatlas .org/data/en/country/16/bd.html [Accessed November 30, 202126, 2021]

Islam SMS. Increasing burden of diabetes in Bangladesh and the role of information technology. Integr Obesity Diabetes. 2016; 2(5): 1-2.

Khan JAM, Ahmed S, Evans TG. Catastrophic healthcare expenditure and poverty related to out-of-pocket payments for healthcare in Bangladesh-an estimation of financial risk protection of universal health coverage. Health Policy Plan. 2017;32(8):1102-1110. https://doi.org/ 10.1093/heapol/czx048.

Khanam R, Ahmed S, Rahman S, Kibria GMA, Syed JRR, Khan AM, Moin SMI, Ram M, Gibson DG, Pariyo G, Baqui AH; Projahnmo Study Group in Bangladesh. Prevalence and factors associated with hypertension among adults in rural Sylhet district of Bangladesh: a cross-sectional study. BMJ Open. 2019;9(10):e026722. https://doi.org/ 10.1136/bmjopen-2018-026722.

Khandker NN, Biswas T, Khan ANS, Hasib E, Rawal LB. Sociodemographic characteristics and tobacco use among the adults in urban slums of Dhaka, Bangladesh. Tob Induc Dis. 2017;15:26. https://doi.org/ 10.1186/s12971-017-0131-1.

Kibria GMA, Swasey K, Hasan MZ, Choudhury A, Gupta RD, Abariga SA, Sharmeen A, Burrowes V. Determinants of hypertension among adults in Bangladesh as per the Joint National Committee 7 and 2017 American College of Cardiology/American Hypertension Association hypertension guidelines. J Am Soc Hypertens. 2018;12(11):e45-e55. https://doi.org/10.1016/j.jash.2018. 10.004 .

Kluge HHP, Wickramasinghe K, Rippin HL, Mendes R, Peters DH, Kontsevaya A, Breda J. Prevention and control of non-communicable diseases 
in the COVID-19 response. Lancet. 2020;395(10238):1678-1680. https://doi.org/10.1016/S0140-6736(20) 31067-9.

Legido-Quigley H, Naheed A, de Silva HA, Jehan I, Haldane V, Cobb B, Tavajoh S, Chakma N, Kasturiratne A, Siddiqui S, Jafar TH; for COBRABPS Study group. Patients' experiences on accessing health care services for management of hypertension in rural Bangladesh, Pakistan and Sri Lanka: A qualitative study. PLoS One. 2019;14(1):e0211100. https://doi.org/10.1371/ journal.pone.0211100.

Liu J, Ren ZH, Qiang H, Wu J, Shen M, Zhang L, Lyu J. Trends in the incidence of diabetes mellitus: results from the Global Burden of Disease Study 2017 and implications for diabetes mellitus prevention. BMC Public Health. 2020 Sep 17;20(1):1415. https://doi.org/ 10.1186/s12889-020-09502-x.

Macquart de Terline D, Kane A, Kramoh KE, Ali Toure I, Mipinda JB, Diop IB, Nhavoto C, Balde DM, Ferreira B, Dèdonougbo Houenassi M, Ikama MS, Kingue S, Kouam Kouam C, Takombe JL, Limbole E, Mfeukeu Kuate L, N'guetta R, Damorou JM, Sesso Z, Sidy Ali A, Perier MC, Azizi M, Empana JP, Jouven X, Antignac M. Factors associated with poor adherence to medication among hypertensive patients in twelve low and middle income SubSaharan countries. PLoS One. 2019; 14(7):e0219266. https://doi.org/10.1371/ journal.pone. 0219266.

Maestre-Muñiz MM, Arias Á, Mata-Vázquez E, Martín-Toledano M, López-Larramona G, Ruiz-Chicote AM, Nieto-Sandoval B, Lucendo AJ. LongTerm Outcomes of Patients with Coronavirus Disease 2019 at One Year after Hospital Discharge. J Clin Med. 2021;10(13):2945. https://doi.org/ 10.3390/jcm10132945.

Mapa-Tassou C, Katte JC, Mba Maadjhou C, Mbanya JC. Economic Impact of Diabetes in Africa. Curr Diab Rep. 2019;19(2):5. https://doi.org/ 10.1007/s11892-019-1124-7.

Mistry SK, Ali ARMM, Yadav UN, Ghimire S, Hossain MB, Das Shuvo S, Saha M, Sarwar S, Nirob MMH, Sekaran VC, Harris MF. Older adults with non-communicable chronic conditions and their health care access amid COVID-19 pandemic in Bangladesh: Findings from a cross-sectional study. PLoS One. 2021;16(7):e0255534. https://doi.org/10.1371/journal.pone. 0255534.

Mwita JC, Francis JM, Omech B, Botsile E, Oyewo A, Mokgwathi M, Molefe-Baikai OJ, Godman B, Tshikuka JG. Glycaemic, blood pressure and low-density lipoprotein-cholesterol control among patients with diabetes mellitus in a specialised clinic in Botswana: a cross-sectional study. BMJ Open. 2019;9(7):e026807. https://doi.org/ 10.1136/bmjopen-2018-026807.

Mwita JC, Godman B, Esterhuizen TM. Statin prescription among patients with type 2 diabetes in Botswana: findings and implications. BMC Endocr Disord. 2020;20(1):36. https://doi.org/ 10.1186/s12902-020-0516-7.

Niaz Q, Godman B, Massele A, Campbell S, Kurdi A, Kagoya HR, Kibuule D. Validity of World Health Organisation prescribing indicators in Namibia's primary healthcare: findings and implications. Int J Qual Health Care. 2019;31(5):338-345. https://doi.org/ 10.1093/intqhe/mzy172.

Nugent R, Brower E, Cravioto A, Koehlmoos T. A cost-benefit analysis of a National Hypertension Treatment Program in Bangladesh. Prev Med. 2017;105S:S56-S61. https://doi.org/10.1016/j.ypmed. 2017.08.014.

Ozawa S, Shankar R, Leopold C, Orubu S. Access to medicines through health systems in low- and middle-income countries. Health Policy Plan. 2019;34(Supplement_3):iii1-iii3. https://doi.org/ 10.1093/heapol/czz119.

Pinchevsky Y, Butkow N, Chirwa T, Raal F. Treatment Gaps Found in the Management of Type 2 Diabetes at a Community Health Centre in Johannesburg, South Africa. J Diabetes Res. 2017;2017:9536025. https://doi.org/10.1155/2017/9536025.
Rafique I, Nadeem Saqib MA, Bashir F, Naz S, Naz S. Comparison of Tobacco Consumption among Adults in SAARC Countries (Pakistan, India and Bangladesh). J Pak Med Assoc. 2018;68(Suppl 2)(5):S2-S6.

Rahman M, Zaman MM, Islam JY, Chowdhury J, Ahsan HN, Rahman R, Hassan M, Hossain Z, Alam B, Yasmin R. Prevalence, treatment patterns, and risk factors of hypertension and pre-hypertension among Bangladeshi adults. J Hum Hypertens. 2018;32(5):334-348. https://doi.org/10.1038/s41371017-0018-x.

Rahman MM, Zhang C, Swe KT, Rahman MS, Islam MR, Kamrujjaman M, Sultana P, Hassan MZ, Alam MS, Rahman MM. Diseasespecific out-of-pocket healthcare expenditure in urban Bangladesh: A Bayesian analysis. PLoS One. 2020; 15(1): e0227565. https://doi.org/10.1371/journal. pone. 0227565 .

Rawal LB, Kanda K, Biswas T, Tanim MI, Poudel P, Renzaho AMN, Abdullah AS, Shariful Islam SM, Ahmed SM. Non-communicable disease (NCD) corners in public sector health facilities in Bangladesh: a qualitative study assessing challenges and opportunities for improving NCD services at the primary healthcare level. BMJ Open. 2019;9(10):e029562. https://doi.org/ 10.1136/bmjopen-2019-029562.

Shariful Islam SM, Lechner A, Ferrari U, Laxy M, Seissler J, Brown J, Niessen LW, Holle R. Healthcare use and expenditure for diabetes in Bangladesh. BMJ Glob Health. 2017; 2 (1): e000033. https://doi.org/10.1136/ bmjgh-2016-000033.

Steenblock C, Schwarz PEH, Ludwig B, Linkermann A, Zimmet P, Kulebyakin K, Tkachuk VA, Markov AG, Lehnert H, de Angelis MH, Rietzsch H, Rodionov RN, Khunti K, Hopkins D, Birkenfeld AL, Boehm B, Holt RIG, Skyler JS, DeVries JH, Renard E, Eckel RH, Alberti KGMM, Geloneze B, Chan JC, Mbanya JC, Onyegbutulem HC, Ramachandran A, Basit A, Hassanein M, Bewick G, Spinas GA, Beuschlein F, Landgraf R, Rubino F, Mingrone G, Bornstein SR. COVID-19 and metabolic disease: mechanisms and clinical management. Lancet Diabetes Endocrinol. 2021;9(11):786-798. https://doi.org/ 10.1016/S2213-8587(21)00244-8.

Tabassum R, Froeschl G, Cruz JP, Colet PC, Dey S, Islam SMS Untapped aspects of mass media campaigns for changing health behaviour towards non-communicable diseases in Bangladesh. Global Health. 2018;14(1):7. https://doi.org/ 10.1186/s12992-018-0325-1.

Tobacco Control Laws. Legislation By Country - Bangladesh. 2021. Available at URL: https://www.tobaccocontrollaws.org/legislation/country/bangladesh/summary. [Accesed November 26, 2021]

\section{How to cite this article}

Akter F, Haque M, Kalemeera F, Kurdi A, Godman B. Key issues surrounding the management of non-communicable diseases including the management of diabetes post COVID-19 among developing countries with a specific focus on Bangladesh. J App Pharm Sci, 2021; 11(12); 2021: i-v. 